\title{
"The influence of indirect monetary tools on price and output: the case of Jordan (1993-2013)"
}

\begin{tabular}{ll} 
AUTHORS & $\begin{array}{l}\text { Usama R. Alqalawi } \\
\text { Hail A. Jemel } \\
\text { Ahmad A. Alwaked } \\
\text { Rasha M.S. Istaiteyeh }\end{array}$ \\
& $\begin{array}{l}\text { Usama R. Alqalawi, Hail A. Jemel, Ahmad A. Alwaked and Rasha M.S. } \\
\text { Istaiteyeh (2017). The influence of indirect monetary tools on price and output: } \\
\text { the case of Jordan (1993-2013). Banks and Bank Systems, 12(1), 8-13. } \\
\text { doi:10.21511/bbs.12(1).2017.01 }\end{array}$ \\
\hline ARTICLE INFO & http://dx.doi.org/10.21511/bbs.12(1).2017.01 \\
\hline DOI & Friday, 24 March 2017 \\
\hline RELEASED ON & $\begin{array}{l}(c c) \text { EY-No } \\
\text { This work is licensed under a Creative Commons Attribution-NonCommercial } 4.0 \\
\text { International License }\end{array}$ \\
\hline LICENSE & "Banks and Bank Systems" \\
\hline JOURNAL & $1816-7403$ \\
\hline ISSN PRINT & $1991-7074$ \\
\hline ISSN ONLINE & LLC “Consulting Publishing Company "Business Perspectives" \\
\hline PUBLISHER & LLC “Consulting Publishing Company "Business Perspectives" \\
\hline FOUNDER &
\end{tabular}



29

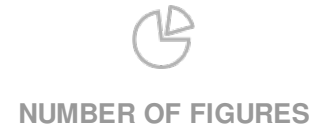

0
NUMBER OF TABLES

5

(C) The author(s) 2022. This publication is an open access article. 


\title{
Usama R. Alqalawi (Jordan), Hail A. Jemel (Jordan), Ahmad A. Alwaked
Rasha M.S. Istaiteyeh (Jordan)
The influence of indirect monetary tools on price and output: the case of Jordan (1993-2013)
}

\begin{abstract}
This research aims to identify the main monetary policy tools in Jordan, then, to estimate their effect on price and output level. A time series data covering the period between 1993 and 2013 were utilized to estimate the targeted models using twostep regression. Firstly, the authors measured the impact of indirect policy tools on money supply and, secondly, they determined the impact of money supply on price and output levels.

Results show that open market operations of the Central Bank of Jordan through issuance of certificates of deposit, especially at the beginning of 1993 and the repurchase agreements have been effective in influencing the money supply in Jordan. Unfortunately, this policy was not able to control the real or nominal output level even though it has an effect on the price level.
\end{abstract}

Keywords: monetary policy, open market operations, required reserve ratio, discount rate, price and output. JEL Classification: E31, E42, E52, E58.

\section{Introduction}

The Jordanian economy faces many internal and external shocks that put pressure on the daily life of Jordanians. These shocks came in shape of sudden economic openness, limitations of internal and external financial resources, deficit in balance of payments, high inflation rate, and prolonged high unemployment rates. In addition, the Jordanian economy depends on foreign aid and remittances. Therefore, Jordan's economy uses monetary policy, directly and indirectly, as a response to these obstacles.

This research adds a new angle to the wide literature that argues about the effectiveness of indirect instruments of monetary policy and its ability to control money supply. These instruments are the required reserve ratio (RRR), the discount rate (DR) and the open market operation (OMO). The Central Bank of Jordan (CBJ) considers these instruments as the most important healing medicine to the fluctuation of output and price level.

The Central Bank of Jordan used to stress on the use of direct instruments during the seventies until the mideighties. Then, a mix of direct and indirect instruments was used until the beginning of the nineties, since then, the concentration has been on using indirect monetary policy tools, especially after the implementation of economic reform policies suggested by the International Monetary Fund (IMF) in the nineties.

(C) Usama R. Alqalawi, Hail A. Jemel, Ahmad A. Alwaked, Rasha M.S. Istaiteyeh, 2017.

Usama R. Alqalawi, Dr., Department of Economics, Hashemite University, Jordan.

Hail A. Jemel, Dr., Department of Economics, Hashemite University, Jordan. Ahmad A. Alwaked, Yarmouk University, Department of Economics, Jordan.

Rasha M.S. Istaiteyeh, Hashemite University, Department of Economics, Jordan.

This is an Open Access article, distributed under the terms of the Creative Commons Attribution-NonCommercial 4.0 International license, which permits re-use, distribution, and reproduction, provided the materials aren't used for commercial purposes and the original work is properly cited.
This research aims to identify the effectiveness of indirect monetary policy instruments and their direct impact on money supply, then, their indirect impacts on price and output. In addition, it provides an evaluation of the CBJ polices, and a guide to policies that provide the best results.

The importance of this research comes from its ability to measure the impact of monetary policy on the size of money supply on Jordan, as well as its ability to achieve stability in the level of domestic prices and whether the policy has a role in promoting economic growth.

This paper answers three questions: First, do indirect monetary policy tools affect the size of money supply in Jordan? Second, does the size of money supply in Jordan affect the domestic price level? Third, does the money supply in Jordan affect the gross domestic product? In order to answer these questions, the paper is organized as follows. In section 1, we discuss the literature review. In section 2, we present the empirical model and data. In section 3 we present the results. Final section concludes the paper.

\section{Literature review}

A considerable number of existing studies have been conducted on the subject of monetary policy and its impact on price level and real income in both developed and developing countries.

Early work in this area can be found in the literature done by Monetarist school. It indicates that inflation is purely a monetary phenomenon, and to solve this problem, it requires controlling the quantity of money. Friedman believes that inflation is a monetary phenomenon caused by money growing more rapidly than real output (Friedman and Schwartz, 1963). In the same direction, Flemming (1978) confirms that monetary expansion is the reason to increase the level of aggregate demand and prices in many countries. Hence, to fight inflation in developed and developing 
countries, monetary authorities should raise interest rate despite the negative effects on economic growth rates and unemployment rates.

Cagan (1973), referring to inflation in the US, showed that the reduction in government expenditures and monetary growth had reduced the inflation in the U.S. from 7\% in 1968 to 3\% in 1969. Furthermore, the reduction in the rate of monetary expansion restricted the size of the total aggregate demand.

More recently, Bustanji (2012) argued that CBJ had stopped issuing certificates of deposit since August 2008 and reduced the interest rate on financial instruments five times by 50 basis points each time, along with reducing the required reserve ratio until it reached $7 \%$ in 2012. In addition, the Central Bank eases some restrictions on the current account, in terms of securities and real estate collateral to give more room for the expansion of bank credit. The study found that changes in the Central Bank interest rates were not reflected heavily on interest rates on loans granted by commercial banks, and the result had a weak influence on the size of the credit facilities.

A study by Tayeb (2011) pointed out the success of the $\mathrm{CBJ}$ in energizing credit facilities by lowering interest rates on monetary tools. Housami (2010) found that there is a strong relation between interest rate for one night, and interest rate in the commercial banks (especially interest rates on deposits and facilities). The increase in discount rate by CBJ resulted in lowering interest rate on loans of commercial banks, and there was a positive impact of open market operations and required reserve on interest rates on commercial bank loans (Hamad, 2009).

Mousa (2010) analyzed the impact of exchange rate changes on demand for money and on trade balance in Jordan. The study concluded that the transmission of signals issued by the CBJ was limited in terms of both the transmission channels of monetary policy signals and with respect to the ultimate goals of monetary policy. Poddar and Hsmik (2006) indicated that CBJ interest rate on deposit certificates for three months affected the interest rate in the money market, and there was a strong relationship between monetary policy tools and interest rates in the banking market.

The most important tool of monetary policy is interest rate on overnight loans between banks, as mentioned by Hamilton and Jing (2012). In European countries that use interest rate as a key tool, the interest rate affects adversely the liquidity held by commercial banks. In contrast, the interbank interest rate affects the lending decisions positively according to Lucchetta (2007). The contractionary monetary policy in Turkey reduced the loans of the small sized and less liquidity banks more than the larger sized and high liquidity banks (Sengonul and Thorbecke, 2005).
The effectiveness of monetary policy was widely discussed in economic literature. Some studies found that monetary policy had smaller impact on output and inflation by time (Boivin and Giannoni, 2006). Other studies argued that monetary policy had improved, especially in developing countries (Cecchetti and Stefan, 2001). In his 2002 study, Khan concluded that monetary policy may become effective if the change in the interest rate is greater than the change in the quantity of money, provided that investment is interest rate sensitive.

The unpredictable and unstable values of the velocity of money, in addition to its contrary movement to the amount of money, made it difficult for Central Banks to control the money supply needed to influence the size of spending, output, and prices, and, hence, lost its ability to manage aggregate demand according to Cargill (1991) and Isard and Rojas-Suarez (1986). Kuttner and Mosser (2002) pointed out that the impact of monetary policy on real economic variables and economic activity became weaker in recent days as a result of financial innovation among other economic factors. Similarly, Aoki et al. (2002) found that housing investment and housing prices in the United Kingdom became less responsive to monetary policy shocks. According to Abdul Karim et al. (2011), monetary policy had a significant effect on Malaysian economic activity. In addition, monetary policy shocks had negatively impacted banks' loan supply.

Cukierman et al. (1992) concluded that there is a strong and negative relationship between price stability and independence of Central Banks in developed countries. Similarly, Grilli et al. (1991) showed an inverse relationship between the independence of Central Banks and the rate of inflation; however, it did not show a relationship between the independence and the rate of Gross Domestic Product.

The aim of CBJ monetary policy is to control the credit of commercial banks to influence the money supply and the volume of domestic liquidity. To achieve this goal, two conditions are required. First, the tools used by the Central Bank including required reserve ratio, discount rate and open market operation have an effective influence on the size of central bank's credit to commercial banks, and, hence, on money supply. Second, the commercial banks and the government need to cooperate with the Central Bank (Cock, 1987). The only available requirement is the availability of cooperation and coordination between the Central Bank and the government on the issue of existence of the certain limits regarding loans issued by the Central Bank. This was explicitly referred to in the instructions and bylaws of central bank (Abu Saleh, 2007). On the other hand, the level of cooperation between the Central Bank and commercial banks were not strong. In some cases, the Central Bank raised interest rates on financial instruments, but the commercial banks re- 
sponded by expanding their credit opposing to the direction of the Central Bank, and the reasons were high liquidity of commercial banks, lack of need for discount rate facilities, weakness of open market operations, and limitations on the issuance of certificates of deposit (Abdel Moneim, 2001).

In Jordan, the process of discount rate was limited and did not exceed 214.5 million JD in 2012, which accounted for only $2 \%$ of CBJ assets, while the CBJ facilities to troubled banks did not exceed 215 million JD during the period (2007-2012) and that was due to the high liquidity of commercial banks by up to $40 \%$ of total deposits. In addition, Jordanian commercial banks invest a significant portion of their assets abroad. For example, in 2012, Jordanian commercial banks balances reached 4437 million JD, which accounted for $25 \%$ of total deposits (CBJ, 2013), and this weakened the effect of monetary policy on reserves and facilities to commercial banks.

\section{Empirical model and data}

The main goal of this section is to analyze the effectiveness of indirect tools of the CBJ in controlling main macroeconomic variables, in particular, price and output level. To achieve this, two regressions were used: first, we used Ordinary Least Square (OLS) method to regress money supply on indirect monetary policy tools. The following equation was estimated:

$$
\begin{aligned}
& M S_{t}=\alpha_{0}+\alpha_{1} D R_{t}+\alpha_{2} R R R_{t}+\alpha_{3} O M O_{t}+ \\
& +\alpha_{4} M S_{t-1}+\mathrm{e}_{\mathrm{t}},
\end{aligned}
$$

where $\mathrm{MS}_{\mathrm{t}}$ is money supply measured in million of JDs defined as M1 money. $\mathrm{DR}_{\mathrm{t}}$ is the discount rate. $\mathrm{RRR}$ is the required reserves ratio levied by $\mathrm{CBJ}$ on commercial banks, $\mathrm{OMO}_{\mathrm{t}}$ is the amount of money used in open market operation by CBJ measured in millions of JDs, $\mathrm{MS}_{\mathrm{t}-1}$ is one year lag of money supply, the subscript $t$ represents the time, and the parameters $\alpha_{0}$ to $\alpha_{4}$ are the estimated coefficients that reflect the effect of the above defined variables on money supply.

Second, we performed two regressions to estimate price and Gross Domestic Product against money supply and other related variables as follows:

$P_{t}=\beta_{0}+\beta_{1} M S_{t}+\beta_{2} M_{t}+\mathrm{e}_{\mathrm{t}}$,

$\mathrm{Y}_{\mathrm{t}}=\gamma_{0}+\gamma_{1} \mathrm{MS}_{\mathrm{t}}+\gamma_{2} \mathrm{~K}_{\mathrm{t}}+\gamma_{3} \mathrm{POP}_{\mathrm{t}}+\mathrm{e}_{\mathrm{t}}$,

where $\mathrm{P}$ is the price level measured using consumer price index with base year 2006, MS is as defined before, $M_{t}$ is the value of imports measured in millions of JDs, and it was included to capture the effect of imported inflation. $\mathrm{Y}_{\mathrm{t}}$ is nominal Gross Domestic Product, $\mathrm{POP}_{t}$ is the population of Jordan, and it was included as a proxy for labor input, $K_{t}$ is the gross capital formation measured in million of JD as a proxy for capital input. And the parameters $\beta_{\mathrm{i}}, \gamma_{\mathrm{j}}$ for $\mathrm{i}=0$ to 2 and for $\mathrm{j}=0$ to 3 , are estimated coefficients that show the degree of reaction of output and price level to changes in the level of money supply and other control variables.

We used yearly time series data covering the period between 1993 and 2013 to estimate the above defined functions. It is worth noting that we tried using quarterly data and the results were almost the same. However, we favored to present yearly data, since the second stage variable such as population and gross capital formation were not available in the form of quarterly data. Three different models were tested to explore the relation between the money supply as the dependent variable and three independent variables as indirect tools of monetary policy: discount rate, required reserve ratio, and open market operations.

\section{The results}

The results are presented in Table 1 below. The models examined the effect of indirect monetary tools on money supply. Our intention was to see the effectiveness of CBJ available monetary policy tools. Three functional forms were estimated; we tried nominal linear specification in model (1), real linear specification in model (2) and nominal loglinear model in model (3) ${ }^{1}$.

Table 1. The effect of indirect monetary policy tools on money supply. Money supply is the dependent

\begin{tabular}{|c|c|c|c|}
\hline & $\begin{array}{l}\text { Nominal model } \\
\text { Linear }\end{array}$ & $\begin{array}{l}\text { Real model } \\
\text { Linear }\end{array}$ & $\begin{array}{l}\text { Nominal mode } \\
\text { Log-linear }\end{array}$ \\
\hline & Model (1) & Model (2) & Model (3) \\
\hline \multirow[t]{2}{*}{ Intercept } & -233.5262 & -9.2007 & -0.5657 \\
\hline & (263.9122) & $(3.0474)^{* * *}$ & $(0.4591)$ \\
\hline \multirow[t]{2}{*}{$\mathrm{MS}_{\mathrm{t}-1}$} & 1.1118 & 0.0119 & 1.0544 \\
\hline & $(0.0216)^{\star \star \star}$ & $(0.0006)^{\star \star \star}$ & $(0.0364)^{\star \star *}$ \\
\hline \multirow[t]{2}{*}{$D R_{t}$} & -37.8492 & -0.4643 & -0.1254 \\
\hline & $(35.2147)$ & $(0.3821)$ & $(0.0702)^{*}$ \\
\hline \multirow[t]{2}{*}{$\mathrm{RRR}_{\mathrm{t}}$} & 30.8666 & 1.0692 & 0.0546 \\
\hline & (47.1191) & $(0.4591)^{\star \star}$ & $(0.0898)$ \\
\hline \multirow[t]{2}{*}{$\mathrm{OMO}_{\mathrm{t}}$} & 0.1993 & 0.2865 & 0.0509 \\
\hline & $(0.0579)^{\star * *}$ & $(0.0599)^{\star \star \star}$ & $(0.0209)^{\star \star *}$ \\
\hline Observation & 19 & 19 & 19 \\
\hline$R^{2}$ & $99.233 \%$ & $97.9212 \%$ & $98.9633 \%$ \\
\hline $\bar{R}^{2}$ & $98.9381 \%$ & $97.1217 \%$ & $98.6868 \%$ \\
\hline $\mathrm{F}$ & $336.4025^{\star \star \star}$ & $122.4717^{\star \star *}$ & $357.9751^{\star \star \star *}$ \\
\hline
\end{tabular}
variable

Note: standard error in parentheses.

$* 10 \%$ significant level, ** 5\% significant level, and ***1\% significant level.

We found that in all three models, the only indirect monetary tool that was always significant is open market operation tool. In model (1), a one thousand JD

\footnotetext{
${ }^{1}$ We did not show real log-linear model, since real value of discount rate and required reserve ratio include negative values.
} 
increase in the securities and bonds held by CBJ will result in an increase in money supply by 199.3 JD on average, model (2) shows that a one thousand JD increase in CBJ holdings of bonds and securities will result in an increase in money supply by 286.5 JD on average, all in real values. However, model (3) shows that $10 \%$ increase in $\mathrm{OMO}$ will result in $0.5 \%$ increase in money supply on average. This suggests that OMO monetary policy tool did affect the money supply even though its affect was not large enough.

Required reserve ratio RRR seemed to have a positive effect on money supply only in real linear model, but the sign of the relation is in contrast with the theory. The results show that a one JD increase in real RRR will lead to 1.069 million JD increase in real money supply on average. This result becomes reasonable if we know that commercial banks in Jordan have a huge excess reserve. According to Khasawneh (2013), the required reserve ratio was equal to 1148 million JD in 2012, whereas the excess reserve reached 2058 million JD in the same period. The discount rate, on the other hand, showed negative effect on money supply only in nominal log-linear model. This result corresponds to the theoretical literature. It demonstrates that a one percent increase in discount rate will lead to $0.1254 \%$ decrease in average money supply.

The inclusion of lagged money supply came was due to the fact that current level of money supply is heavily determined by its past level, and not including the lagged money supply will lead to omitted variable bias. All three models showed positive relation between the current level and the past level. All the above results suggest that monetary policy had limited effect on money supply, and open market operation was the most important tool in controlling the money supply during the period of the study.

In stage two, we regressed money supply and other related variables on output and price level separately. The aim was to find out whether the money supply resulting from changing the indirect tool of monetary policies really affects the main macroeconomic target variables. To fulfill this aim, we launched two sets of regressions. The first set of regressions shown in Table 2 tested the existence relation between money supply and price. We tried four different specifications. Firstly, nominal linear specification using actual value of money supply was presented in model (4). Secondly, nominal linear specification using model (1) forecasted value of money supply MS1 $1_{\mathrm{t}}$ was presented in model (5). Thirdly, nominal linear specification using model (2) forecasted value of money supply MS2 $2_{t}$ was presented in model (6). Finally, nominal linear specification using model (3) forecasted value of money supply MS3 $3_{\mathrm{t}}$ was presented in model (7).
Table 2. The effect of money supply on price level (Price $=100$ in 2006). Price as the dependent variable

\begin{tabular}{|c|c|c|c|c|}
\hline & $\begin{array}{l}\text { Nominal Model } \\
\text { Linear }\end{array}$ & $\begin{array}{l}\text { Nominal Model } \\
\text { Linear }\end{array}$ & $\begin{array}{l}\text { Nominal Model } \\
\text { Linear }\end{array}$ & $\begin{array}{l}\text { Nominal } \\
\text { Model } \\
\text { Linear }\end{array}$ \\
\hline & Model (4) & Model (5) & Model (6) & Model (7) \\
\hline \multirow[t]{2}{*}{ Intercept } & 67.2583 & 65.1189 & 68.4780 & 64.8248 \\
\hline & $(5.0243)^{\star \star \star}$ & $(4.2806)^{\star \star \star}$ & $(5.2265)^{\star \star \star}$ & $(3.4592)^{\star \star \star}$ \\
\hline \multirow[t]{2}{*}{$M_{t}$} & 0.0023 & 0.0017 & 0.0030 & 0.0013 \\
\hline & $(0.0007)^{\star * *}$ & $(0.0009)^{* *}$ & $(0.0008)^{* * *}$ & $(0.0009)$ \\
\hline \multirow[t]{2}{*}{$\mathrm{MS}_{\mathrm{t}}$} & 0.0045 & & & \\
\hline & $(0.0016)^{\star \star}$ & & & \\
\hline \multirow[t]{2}{*}{$M S 1_{t}$} & & 0.0057 & & \\
\hline & & $(0.0019)^{\star * *}$ & & \\
\hline \multirow[t]{2}{*}{$\mathrm{MS} 2 \mathrm{t}$} & & & 0.0030 & \\
\hline & & & $(0.0020)$ & \\
\hline \multirow[t]{2}{*}{$M S 3_{t}$} & & & & 0.0065 \\
\hline & & & & $(0.0018)^{\star * *}$ \\
\hline $\begin{array}{l}\text { Observa- } \\
\text { tion }\end{array}$ & 20 & 18 & 18 & 19 \\
\hline$R^{2}$ & $98.8503 \%$ & $98.7565 \%$ & $98.2409 \%$ & $99.0545 \%$ \\
\hline $\bar{R}^{2}$ & $98.6348 \%$ & $98.4901 \%$ & $97.8639 \%$ & $98.8654 \%$ \\
\hline $\mathrm{F}$ & $458.5718^{\star \star \star}$ & $370.6276^{\star \star *}$ & $260.6183^{\star * *}$ & $523.8122^{\text {***}}$ \\
\hline
\end{tabular}

Note: standard error in parentheses.

$* 10 \%$ significant level, ** $5 \%$ significant level and $* * * 1 \%$ significant level.

Results indicated that price level was positively affected by money supply on all models except the model that forecast the value of money supply using model (2) specification. This means that as money supply increases, the price will increase and this matches the theoretical expectation. The magnitude of the effect of the money supply on price is small, thus, as money supply increases by 1 million JD, the consumer price index will change by 0.005 point on average for all models.

We tested the effect of imports on price level, and we found that as imports increased, price level increased. And this suggests that some part of inflation in Jordan is an imported inflation. However, we can note that the imported inflation was less than non imported inflation resulting from the increase in money supply. The results support that monetary policy does affect the price level, and that monetary authority has the ability to control prices using $\mathrm{OMO}_{\mathrm{t}}$ monetary tool.

Table 3 showed a second set of regressions, designated to test the existence of relation between money supply and output. We performed four attempts two of them with linear specification, and two with log linear specification. Interestingly, all attempts showed no effect of money supply on nominal or real $\mathrm{GDP}_{\mathrm{t}}$. population as proxy of labor input $\mathrm{L}_{t}$ was significant with positive correct sign in all four models; similarly, the capital input $\mathrm{K}_{\mathrm{t}}$ took the right sign in all regressions, though it appeared to be significant only in nominal linear and log-linear model. This may suggest that, al- 
though monetary policy can affect money supply, money supply has no ability to stimulate real or nominal GDP ${ }_{\text {t }}$.

Table 3. The effect of money supply on output level. GDP is the dependent variable

\begin{tabular}{lcccc}
\hline & $\begin{array}{c}\text { Nominal model } \\
\text { Linear } \\
\text { Model (8) }\end{array}$ & $\begin{array}{c}\text { Real model } \\
\text { Linear } \\
\text { Model (9) }\end{array}$ & $\begin{array}{c}\text { Nominal model } \\
\text { Log-linear } \\
\text { Model (10) }\end{array}$ & $\begin{array}{c}\text { Real model } \\
\text { Log-linear } \\
\text { Model (11) }\end{array}$ \\
\hline Intercept & -12456.19 & -6661.782 & -39.7148 & -20.5390 \\
& $(5902.018)^{*}$ & $(1724.407)^{* * *}$ & $(8.3334)^{* * *}$ & $(3.9575)^{* * *}$ \\
$\mathrm{MS}_{\mathrm{t}}$ & 0.1041 & 0.0453 & -0.0266 & 0.0616 \\
& $(0.2410)$ & $(0.1255)$ & $(0.1379)$ & $(0.0693)$ \\
$\mathrm{K}_{\mathrm{t}}$ & 0.6872 & 0.1957 & 0.2102 & 0.0715 \\
& $(0.2117)^{* * *}$ & $(0.1280)$ & $(0.07726)^{* *}$ & $(0.0491)$ \\
Ppp $\mathrm{t}$ & 0.00312 & 0.0023 & 3.0353 & 1.8204 \\
& $(0.0012)^{* *}$ & $(0.0003)^{* * *}$ & $(0.5975)^{* * *}$ & $(0.2859)^{* * *}$ \\
Obser- & 20 & 20 & 20 & 20 \\
vation & & 20 & & \\
$R^{2}$ & $99.6035 \%$ & $99.6638 \%$ & $99.6703 \%$ & $99.6752 \%$ \\
$\bar{R}^{2}$ & $99.4977 \%$ & $99.5742 \%$ & $99.5824 \%$ & $99.5886 \%$ \\
$\mathrm{~F}$ & $941.9074^{* * *}$ & $1111.728^{* * *}$ & $1133.637^{* * *}$ & $1150.886^{* * *}$ \\
\hline
\end{tabular}

Note: standard error in parentheses.

* $10 \%$ significant level, ** $5 \%$ significant level and $* * * 1 \%$ significant level.

Finally, we wondered if the effect of money supply on nominal or real $\mathrm{GDP}_{\mathrm{t}}$ may appear more clearly from the part of money supply that was affected by monetary tools. In order to test this idea, six more regressions were presented. We used nominal $\mathrm{GDP}_{t}$ as dependent variable in Table 4 , and real $\mathrm{GDP}_{\mathrm{t}}$ as dependent variable in Table 5.

Table 4. The effect of money supply on output. Nominal GDP as the dependent variable

\begin{tabular}{|c|c|c|c|}
\hline & $\begin{array}{l}\text { Nominal model } \\
\text { Linear } \\
\text { Model (9) }\end{array}$ & $\begin{array}{l}\text { Nominal model } \\
\text { Linear } \\
\text { Model (10) }\end{array}$ & $\begin{array}{l}\text { Nominal model } \\
\text { Linear } \\
\text { Model (11) }\end{array}$ \\
\hline Intercept & $\begin{array}{c}0.6522 \\
(7012.289)\end{array}$ & $\begin{array}{c}-5379.491 \\
(0.2395)\end{array}$ & $\begin{array}{c}572.9745 \\
(5197.406)\end{array}$ \\
\hline$M S 1_{t}$ & $\begin{array}{l}0.91632 \\
(0.5741)\end{array}$ & & \\
\hline$M S 2_{t}$ & & $\begin{array}{c}0.2925 \\
(0.2395)\end{array}$ & \\
\hline$M S 3_{t}$ & & & $\begin{array}{c}1.0714 \\
(0.4324)^{*}\end{array}$ \\
\hline$K_{t}$ & $\begin{array}{c}0.5705 \\
(0.2753)^{\star}\end{array}$ & $\begin{array}{c}0.9351 \\
(0.1751)^{\star * \star}\end{array}$ & $\begin{array}{c}0.3478 \\
(0.2730)\end{array}$ \\
\hline $\mathrm{Pop}_{\mathrm{t}}$ & $\begin{array}{c}0.0002 \\
(0.0016)\end{array}$ & $\begin{array}{c}0.0016 \\
(0.0009)\end{array}$ & $\begin{array}{l}0.0001 \\
(0.0012)\end{array}$ \\
\hline Observation & 18 & 18 & 19 \\
\hline$R^{2}$ & $99.5992 \%$ & $99.5502 \%$ & $99.6877 \%$ \\
\hline $\bar{R}^{2}$ & $99.4759 \%$ & $99.4118 \%$ & $99.5985 \%$ \\
\hline $\mathrm{F}$ & $807.6172^{\star \star *}$ & $719.3361^{* \star *}$ & $1117.307^{\star \star *}$ \\
\hline
\end{tabular}

Note: standard error in parentheses.

* $10 \%$ significant level, ** $5 \%$ significant level and $* * * 1 \%$ significant level.

We tried three different specifications. Firstly, nominal linear specification using model (1) forecasted value of money supply $\mathrm{MS}_{\mathrm{t}}$, and was presented in model (9).
Secondly, nominal linear specification using model (2) forecasted value of money supply MS2 ${ }_{\mathrm{t}}$, and was presented in model (10). Finally, nominal linear specification using model (3) forecasted value of money supply $\mathrm{MS}_{\mathrm{t}}$, and was presented in model (11). The results show again that nominal $\mathrm{GDP}_{\mathrm{t}}$ was not affected by money supply except if we use model (3) to forecast money supply $\mathrm{MS}_{\mathrm{t}}$. In that case, a one JD increase in nominal money supply will lead to 1.07 increase in nominal GDP. In addition, capital and labor in the later model were not significant.

Likewise, real money supply forecast using model (1), (2) and (3) had no effect at all on real GDP , labor input was the major factor that influenced real $\mathrm{GDP}_{\mathrm{t}}$ in all tested models in Table 5. That is, an increase in labor by one person, will lead to an increase on $\mathrm{RGDP}_{t}$ by 200,000 JD yearly on average.

Table 5. The effect of money supply on output real $\mathrm{GDP}_{\mathrm{t}}$ as the dependent variable

\begin{tabular}{|c|c|c|c|}
\hline & $\begin{array}{l}\text { Real model } \\
\text { Linear } \\
\text { Model (9) }\end{array}$ & $\begin{array}{l}\text { Real model } \\
\text { Linear } \\
\text { Model (10) }\end{array}$ & $\begin{array}{l}\text { Real model } \\
\text { Linear } \\
\text { Model (11) }\end{array}$ \\
\hline \multirow[t]{2}{*}{ Intercept } & -6113.509 & -6048.358 & -5558.408 \\
\hline & $(1996.605)^{\star \star \star}$ & $(1771.435)^{\star \star \star}$ & $(2499.408)^{*}$ \\
\hline \multirow[t]{2}{*}{$M S 1_{t}$} & 0.1754 & & \\
\hline & $(0.2013)$ & & \\
\hline \multirow[t]{2}{*}{$M S 2_{t}$} & & 0.1231 & \\
\hline & & $(0.1004)$ & \\
\hline \multirow[t]{2}{*}{$M S 3_{t}$} & & & 0.1625 \\
\hline & & & $(0.2347)$ \\
\hline \multirow[t]{2}{*}{$\mathrm{K}_{\mathrm{t}}$} & 0.1656 & 0.2235 & 0.1841 \\
\hline & $(0.1356)^{\star}$ & $(0.2235)$ & $(0.1347)$ \\
\hline \multirow[t]{2}{*}{ Pop $_{t}$} & 0.0021 & 0.0021 & 0.0020 \\
\hline & $(0.0005)^{\star * *}$ & $(0.0004)^{\star \star *}$ & $(0.0006)^{\star * *}$ \\
\hline Observation & 18 & 18 & 19 \\
\hline$R^{2}$ & $99.6376 \%$ & $99.6529 \%$ & $99.66413 \%$ \\
\hline $\bar{R}^{2}$ & $99.5260 \%$ & $99.5461 \%$ & $99.5388 \%$ \\
\hline $\mathrm{F}$ & $893.4408^{* * *}$ & $933.0109^{* * *}$ & $972.1685^{\star \star \star}$ \\
\hline
\end{tabular}

Note: standard error in parentheses.

* $10 \%$ significant level, ** $5 \%$ significant level and *** $1 \%$ significant level.

\section{Conclusion}

This research utilized yearly data from Jordanian monetary sector that cover the period between 1993 and 2013 to test the effect of monetary indirect polices represented by discount rate, required reserve ratio, and open market operation, on two macroeconomic target variables: price, and output level. A two-stage methodology was used. The first stage tested the stimulated effect of indirect monetary tools on money supply. We found that there was significant effect for open market operation policy on nominal and real money supply in both linear and log-linear models. Discount rate monetary tool was significant in real model, while the required reserve ratio was significant in the 
log linear model. In the second stage, we regressed money supply first against price level, then, against output level. Results also showed that money supply significantly and positively affected the price level. In contrast, the results show that nominal and real GDP was not affected by money supply in almost all models.

Results suggest that in the period of study, the monetary authority had a limited influence on money supply using indirect tool of monetary policy.
Only open market operation tool had positive effect on money supply. This influence, in turn, was not able to impact real or nominal GDP and its effect was restricted to price level only. Supporting the Friedman and Schwartz (1963) theory, this suggests that monetary policy was able to maintain the value of money, considering that the value of money is the inverse of the general price level. In addition, we found that inflation was partially imported, and the imported inflation was less than non imported inflation resul-ting from the increase in money supply.

\section{References}

1. Abdel, Moneim S.A. (2001). Evaluation of monetary policy in Jordan during the period 1970-1999, Irbid journal for researches and studies, Special issue, Irbid University, pp. 1-42.

2. Abu Saleh, R. (2007). The degree of independence of the Jordanian central bank and influencing factors, Unpublished master thesis, Al Albyet University.

3. Aoki, K., Proudman, J. \& Vlieghe, G. (2002). Houses as collateral: has the link between house prices and consumption in the UK changed? Federal Reserve Bank of New York, Economic Policy Review, 8 (1), pp. 163-78.

4. Boivin, J. \& Giannoni, M.P. (2006). Has monetary policy become more effective? The Review of Economics and Statistics, 88 (3), pp. 445-462.

5. Bustanji, J. (2012). The role of the central bank of Jordan in capturing the repercussions of the global financial crisis on the banks working in Jordan, Unpublished master thesis, Middle East University, Jordan.

6. Cagan, P. (1973). A New Look at Inflation: Economic Policy in the Early 1970s.

7. Cargill, T.F. (1991). Money, the financial system, and monetary policy. Prentice Hall.

8. Cecchetti, S.G. \& Krause, S. (2001). Financial structure, macroeconomic stability and monetary policy, No. w8354, National Bureau of Economic Research.

9. Cukierman, A., Web, S.B. and Neyapti, B. (1992). Measuring the independence of central banks and its effect on policy outcomes, The world bank economic review, 6 (3), pp. 353-398.

10. Flemming, J.S. (1978). The economic explanation of inflation. The Political Economy of Inflation, Salisbury, pp. 13-36.

11. Friedman, M. \& Schwartz, A.J. (1963). A monetary history of the United States, 1867-1960, NBER Books.

12. Friedman, M. \& Schwartz, A.J. (1975). Money and business cycles, The State of Monetary Economics, pp. 32-78. NBER.

13. Grilli, V., Masciandaro, D. \& Tabellini, G. (1991). Political and monetary institutions and public financial policies in the industrial countries, Economic policy, 6 (13), pp. 342-392.

14. Hamad, A. (2009). The effect of monetary policy on the interest rates in Jordanian commercial banks 1993-2007, unpublished master thesis, Aal Albayet University, Jordan.

15. Hamilton, J.D. \& Wu, J.C. (2012). The effectiveness of alternative monetary policy tools in a zero lower bound environment, Journal of Money, Credit and Banking, 44 (s1), pp. 3-46.

16. Housami, N. (2010). The effect of monetary policy on exchange rates and the interest rates Policy, Case of jordan. Economic Observatory, University of Jordan.

17. Isard, P. \& Rojas-Suarez, L. (1986). Velocity of money and the practice of monetary targeting: Experience, theory, and the policy debate. IMF.

18. Jordan Central Bank. (2013). Monthly Statistical Bulletin, issue 5, April, p. 2.

19. Jordan Central Bank (2012). Yearly statistical series, issue 5, p. 26.

20. Karim, M.Z.A., Harif A.A.M. \& Adziz, A. (2006). Monetary policy and sectoral bank lending in Malaysia, Global Economic Review, 35 (3), pp. 303-326.

21. Khan, M.S., Nsouli, S.M. and Wong, C.H. (eds). (2002). Macroeconomic management: programs and policies. International Monetary Fund.

22. Khasawneh, A. (2013). Excess Reserve Holdings of Jordan Commercial Banks: VARX Implementation, International Journal of Economics and Finance, 5, no. 11, p. 152.

23. Kock, D.M. (1938). Central banking. [Al makhazoomy, A. (1987). An Arabic translated version].

24. Kuttner, K.N. \& Mosser, P.C. (2002). The monetary transmission mechanism: some answers and further questions, Federal Reserve Bank of New York Economic Policy Review, 8 (1), pp. 15-26.

25. Lucchetta, M. (2007). What do data say about monetary policy, bank liquidity and bank risk taking? Economic Notes, 36 (2), pp. 189-203.

26. Mousa, N.Y.A. (2010). Monetary policy and the role of exchange rate: the case of Jordan, Doctoral dissertation, University of Birmingham.

27. Poddar, Khachatryan, H. \& Sab, R. (2006). The monetary transmission mechanism in Jordan, IMF Working Papers, 6048(200), pp. 1-28.

28. Sengonul, A. \& Thorbecke, W. (2005). The effect of monetary policy on bank lending in Turkey, Applied Financial Economics, 15 (13), pp. 931-934.

29. Tayeb, S. (2011). The Effect of Fiscal and Monetary Policies undertaken by Jordanian Government as Consequences of international financial crisis, Unpublished research, Mouta University. 